\title{
The Diurnal and Semidiurnal Patterns of Rainfall and its Correlation to the Stream Flow Characteristic in the Ciliwung Watershed, West Java, Indonesia
}

\author{
Edi Riawan ${ }^{1, *}$, Tri Wahyu Hadi ${ }^{1}$, Hadi Kardhana ${ }^{2,3}$, Dadang K. Mihardja ${ }^{4}$, and Benyamin Sapiie ${ }^{5}$ \\ ${ }^{1}$ Atmospheric Sciences Research Group, Institut Teknologi Bandung \\ ${ }^{2}$ Water Resources Engineering Research Group, Institut Teknologi Bandung \\ ${ }^{3}$ Infrastructure and Regional Development Research Centre, Institut Teknologi Bandung \\ ${ }^{4}$ Oceanography Research Group, Institut Teknologi Bandung \\ ${ }^{5}$ Geology Research Group, Institut Teknologi Bandung
}

\begin{abstract}
Based on the data analysis of 16 years of TMPA dataset, the common patterns of rainfall over the Ciliwung River Basin are diurnal and semidiurnal. Those patterns can be associated by a stationary or moving rainstorm with different magnitude and direction. Based on hydrological model simulations, both the pattern and movement have a significant role to the discharge. At the downstream area, the discharge that triggered by semidiurnal pattern of rainfall can produces higher peak discharge and longer flood duration than diurnal pattern. This result open possibility to improve our prediction on design discharge.
\end{abstract}

\section{Introduction}

The spatial-temporal characteristics of rainfall have significant role on characteristic of stream flow [1]-[4]. These characteristics strongly effected by moving rainstorm [2]. The greatest effect of moving rainstorms occurred when the velocity of storms is half of stream flow velocity in downslope direction [1]. de Lima and Singh simulated the moving rainstorm using numerical and physical models, and concluded the runoff characteristics are sensitive to the speed and direction of storm movement [3], [4].

An analysis of the spatial-temporal characteristic can be simplified by analyze the spatial distributions and the temporal patterns of rainfall. Based on the four severe floods that occurred in Jakarta, the spatial-temporal variation is inherent characteristics on the extreme rainfalls. Table 1 showed the distribution of rainfall and storm motions on flood events in Jakarta. The distribution of rainfall can be concentrated on upstream areas (example: 1996 and 2007 flood events), or downstream areas (example: 2002 and 2013 flood events) and the storms can moving to downslope (example: 2002) or upslope (example: 2013) or downslope-upslope (example: 2007).

Table 1. The rainstorm characteristics in the Ciliwung Watershed on extreme

\begin{tabular}{|l|l|l|}
\hline \multirow{2}{*}{$\begin{array}{l}\text { Flood } \\
\text { events }\end{array}$} & \multicolumn{2}{|l|}{ Heavy Rainfall Characteristic } \\
\cline { 2 - 3 } & Spatial & temporal \\
\hline
\end{tabular}

\begin{tabular}{|c|c|c|c|}
\hline \multirow{2}{*}{1} & \multirow{2}{*}{$\begin{array}{l}\text { January } \\
1996 \\
\end{array}$} & Upstream & - \\
\hline & & & \\
\hline \multirow{2}{*}{2} & \multirow{2}{*}{$\begin{array}{l}\text { January } \\
2002\end{array}$} & downstream & downslope \\
\hline & & [5] & {$[6][7]$} \\
\hline \multirow{2}{*}{3} & \multirow{2}{*}{$\begin{array}{l}\text { February } \\
2007\end{array}$} & upstream & $\begin{array}{l}\text { Downslope- } \\
\text { upslope }\end{array}$ \\
\hline & & {$[7],[8]$} & \\
\hline \multirow{2}{*}{4} & \multirow{2}{*}{$\begin{array}{l}\text { January } \\
2013\end{array}$} & downstream & upslope \\
\hline & & [9] & \\
\hline
\end{tabular}

The objective of this study is to study the common characteristics of rainfall and related to peak flow and floods durations. The characteristics shown by: spatial distributions (upstream, midstream, downstream), temporal patterns of rainfall and its combinations (diurnal and semidiurnal).

\section{Data and Method}

\subsection{Study Area}

This study focuses on small river basin in the tropical area, ie: the Ciliwung River Basin (CRB). CRB is the watershed with highest flood risk in Indonesia. Ciliwung Rivers is the largest river which is through DKI Jakarta, the capital city of Indonesia. In the last 20 years, the Ciliwung River contributed to the 3 major devastating floods in DKI Jakarta, ie early February 2002 and 2007 and the end of January 2013. Floods that occurred in 2007 resulted in losses reached 5.6 trillion rupiahs [10].

\footnotetext{
* Corresponding author: ediriawan@meteo.itb.ac.id
} 
Ciliwung River was diverted to West Flood Canal at Manggarai hydrological station (HS). This condition increasing the complexity of hydrological analysis in $\mathrm{CRB}$, especially for the downstream area after the diversion. For this reason, this study is limited to the area before the diversion, precisely at M.T Haryono HS. Total area of CRB for an outlet at M.T Haryono HS reached 352 $\mathrm{km}^{2}$ (Fig.1). CRB has a complex topography. The upstream area consists of steep mountains with maximum altitude above $2982 \mathrm{~m}$. The downstream area is a flat floodplain.

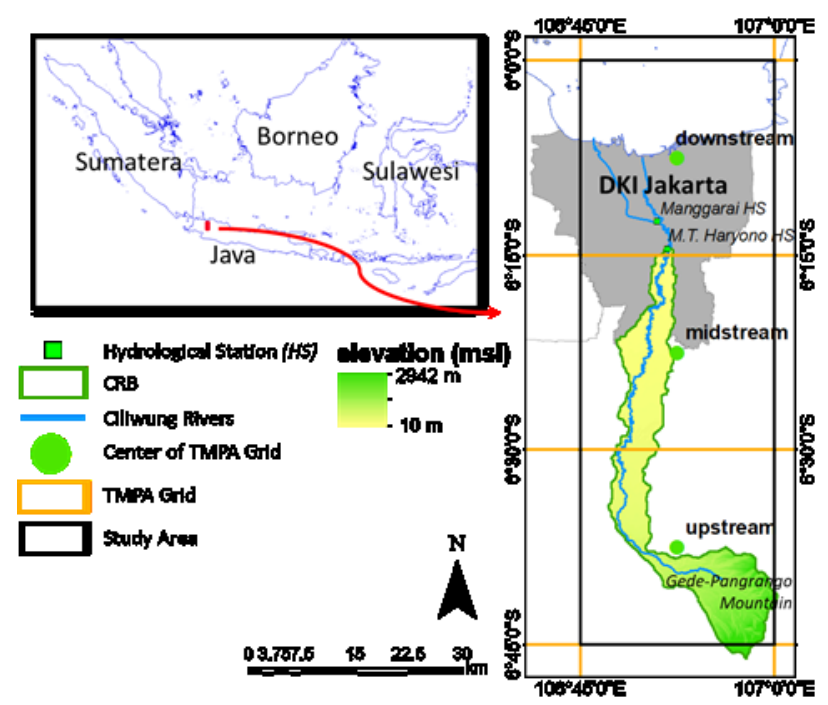

Fig. 1. The map of study area.

\subsection{Rainfall Data}

The Tropical Rainfall Measuring Mission (TRMM) Multisatelite Precipitation Analysis (TMPA) was used in this study. The TMPA was produced by a calibrationbased sequential scheme for combines multiple satellites to produce precipitation data at fine scales, $0.25^{\circ} \times 0.25^{\circ}$ and 3 hourly, and available since 1998 [2]. This data was compare to other TRMM-derived products to analysis the extreme rains over the Maritime Continent [3]. Nesbitt and Zipser (2003) used the previous product of TMPA to analysis the diurnal cycle of rainfall in the tropical area [4].

This study used 16 years period of TMPA data, 19982013 to produce the general pattern of daily rainfall over CRB. There is 3 grid over CRB named by the upstream, midstream and downstream grid (Fig 1).

\subsection{Diurnal variation analysis method}

The diurnal variation of rainfall identified composite analyzes according to the method that proposed by Ruhf and Cutrim (2003). The 3-hour rainfall data from TMPA was accumulated for the same hour (hh), for each month $(\mathrm{mm})$, of 16 years (yy) study periods, then divided by the number of years. This method produced the average annual accumulation rainfall for each 3-hour ( $\mathrm{mm} /$ year).
However, since monthly analysis is required, the month is considered as a calculated variable (equations (1)). The calculation result was plotted on the hour-month chart for represented the variability of diurnal variation for each month, Fig 3 and Fig $\mathbf{4}$ are the results of this method.

$$
\text { - } P(h h, m m)=\frac{\sum_{y y=1}^{y y m a x} \sum_{d d=1}^{d d m a x} P_{y e a r, d a y}(h h, m m)}{16}
$$

\subsection{Hydrological model and simulation scnearios}

The distributed hydrological model was used to investigate the influence of diurnal characteristics of rainfall to overland flow at CRB. The numerical model used in this study is Gridded Surface Subsurface Hydrological Analysis (GSSHA) [2]. GSSHA is the distributed and physics-based hydrological modeling. The model also has two dimensional (2D) overland flow and 1D stream flow that has been fully coupled.

The domain of the model is Ciliwung Watershed from the upstream area at Gede-Pangrango Mountain area to the outlet at M.T. Haryono hydrological station, DKI Jakarta Province. The domain has $250 \mathrm{~m}$ horizontal resolution and divided by $234 \times 99$ grids and 5704 grid is active cell (inside watershed). Fig.1 and Fig.2 showed the domain of the hydrological model.

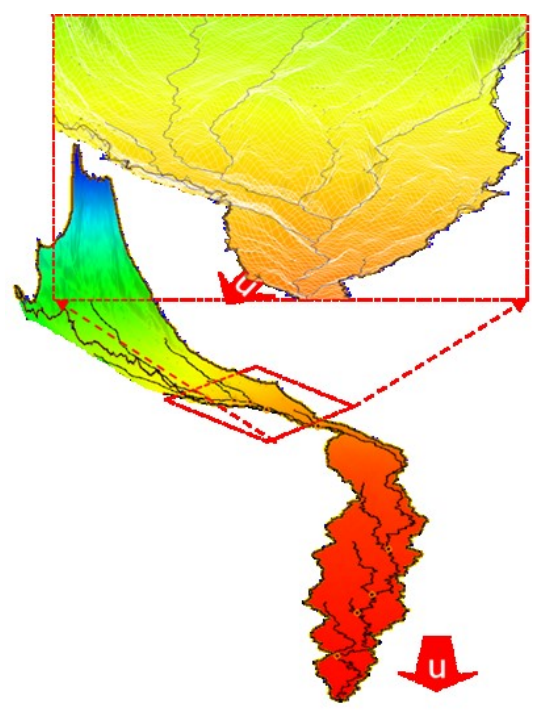

Fig. 2. Hydrological Domain in $2 \mathrm{D}$ visualization

The topography, rivers, and land cover data are GISvector dataset with scale 1:25,000 which can be downloaded from the website of Badan Informasi Geospasial (BIG) at http://portal.ina-sdi.or.id/. The contour topography was converted to DEM and used as the surface elevation of the model. The river data was used to correct the DEM data, especially in the gently slope area. The land cover dataset is used as a proxy for roughness parameterization. There are four classifications for roughness parameterization that is: forest, cultivated area, water body, and urban area. The roughness value for 
each land cover classification was taken into account in the calibration processes.

This model was run to simulate two following scenarios, namely (1) the combination of rainfall pattern on upstream, midstream, and downstream area that produced by TMPA data analysis (section 3.1), and (2) the stationary and moving rainfall $(\sim 5 \mathrm{~m} / \mathrm{s})$ based on previous research.

\section{Result and Discussion}

\subsection{Variation of Diurnal Rainfall}

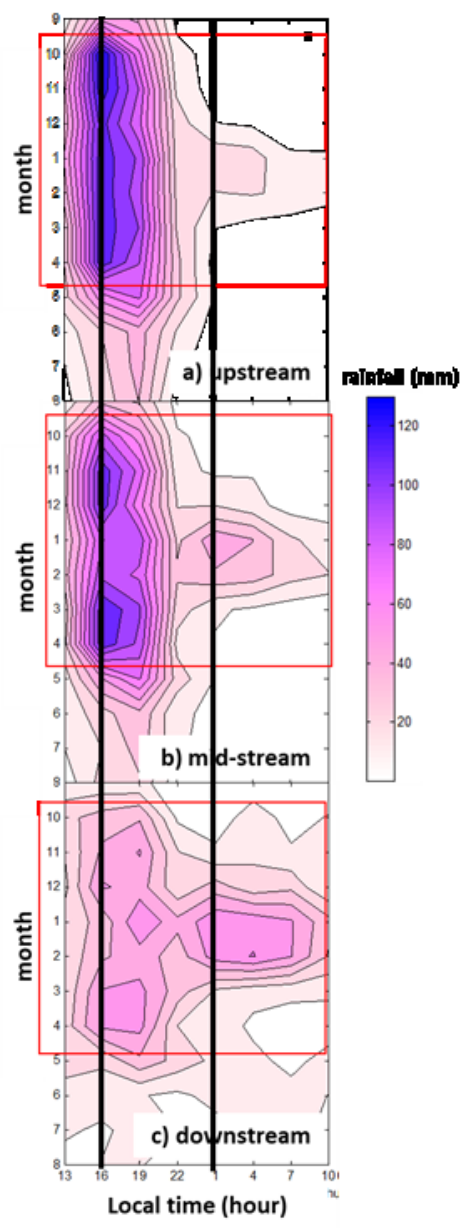

Fig. 3. Total annual rainfall for each month and each hour in (a) upstream, (b) midstream and (c) downstream area of CBR.

The diurnal variation of rainfall in CRB variated for each location and month. Fig. 3 shows the average of the 16 years of total annual rainfall for each month and each hour in the upstream, midstream, and downstream area of CRB based on TMPA data. The figure can represent the frequency of rain for each location, hour and month. In upstream and midstream area, the rain commonly occurs in afternoon. The morning rain, the rain that occurs in the morning, is more frequent in the midstream area than upstream. In the downstream, the morning rain becomes dominant than the afternoon rain. This indicates the diurnal patterns getting more dominant in the upstream area and vice versa for the semidiurnal pattern, getting more dominant in the downstream area. Where the diurnal pattern is a pattern with single rain event in a day and the semidiurnal pattern has two rain events in a day.

The domination of semidiurnal pattern in downstream area was studied by Siswanto et al. (2016) based on long term period of observation data at the Jakarta Observatory meteorological station [3]. Semidiurnal pattern getting dominant in December-January-February (DJF) than the other month.

May to September is a dry month and August is the driest month, therefore those months will not be further analyzed in this study.

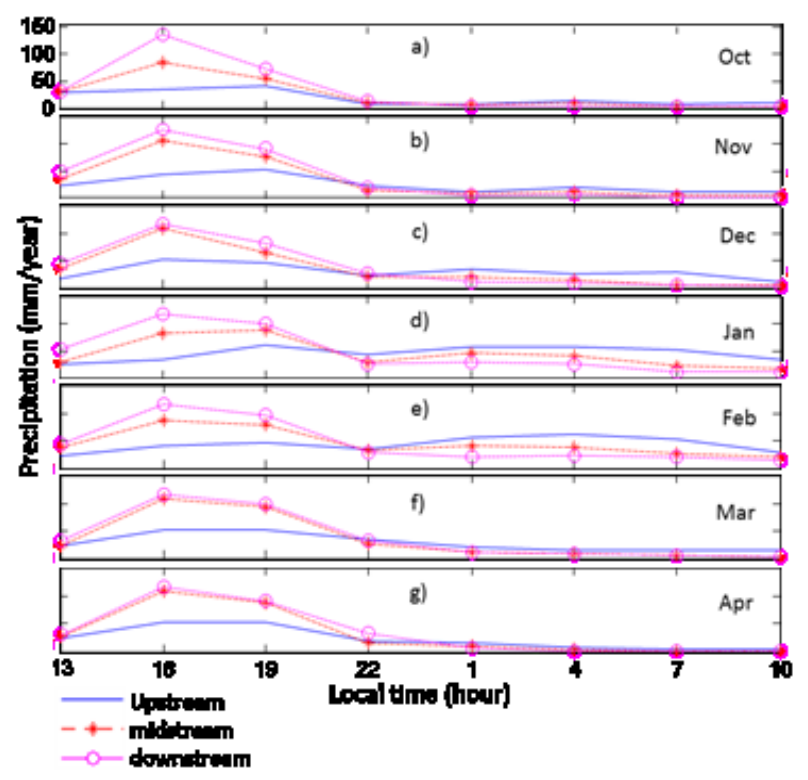

Fig. 4. The general patterns of diurnal rainfall for each month from October to April in three grid of TMPA data in $\mathrm{CRB}$

Fig. 4 is a simple form of the Fig.3 to classify the general pattern of rainfall in CRB. The diurnal patterns of rainfall dominated the whole area of CRB in March-April. In October-November, only the downstream area dominated by the semidiurnal pattern. And on the December only upstream area which dominated by the diurnal pattern. The semidiurnal pattern becomes dominant in the whole area of CRB in January and February which is the months with most frequent major floods in CRB. This result indicated correlations between semidiurnal patterns and the major floods.

The correlation of the diurnal variation of rainfall and extreme discharge conducted by hydrological model. To perform this method, simple patterns of rainfall is needed to produce the simulation scenarios but still represent the patterns that exist in CRB. Fig. 5 shows the overlay of the 
topographic profile, grid of TMPA and domain of hydrological model along the Ciliwung River. The figure shows only the midstream and upstream areas within the hydrological model domain. Consequently, the hydrological simulation only involves patterns combinations in the upstream and midstream areas. There are three combinations of patterns, ie DD and SS respectively for diurnal and semidiurnal in the whole domains and DS for diurnal in upstream and semidiurnal in downstream.

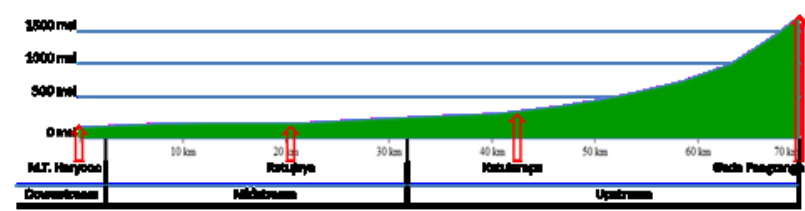

Fig. 5. Topographic profile of Ciliwung River from the upstream and the position of hydrology station (red arrows) and TMPA grid boundary (vertical black lines)

Fig. 6 shows the cumulative probability function of each rain event characteristics based on TMPA data. Fig.6.b shows the most rain occurs in 3-hour duration. The maximum rainfall intensity in one rain event is about 15 $\mathrm{mm} /$ hour (Fig.6.c), although the maximum intensity can reach $40 \mathrm{~mm} /$ hour but this condition did not occur continuously during one rain event. Based on this result, one rain event in the rainfall scenarios can be simplified by a rain with 3-hour of duration and $15 \mathrm{~mm} /$ hour of rainfall intensity. In afternoon, the rain occurs at 14.30 to 17.30 LT and in the morning the rain occurs at 23.30 to 02.30 LT. To clarify the difference between the effects caused by diurnal and semidiurnal patterns, rainfall volume needs to be maintained by making the rainfall intensity become $7.5 \mathrm{~mm}$ / hour for semidiurnal patterns.

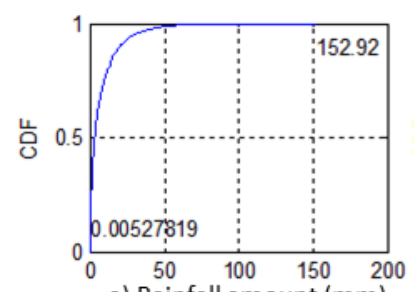

a) Rainfall amount (mm)

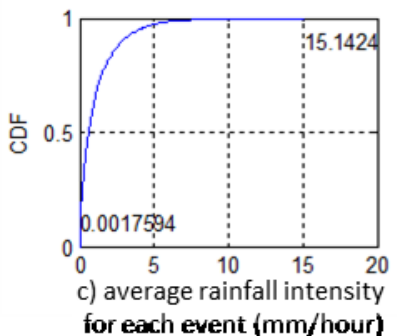

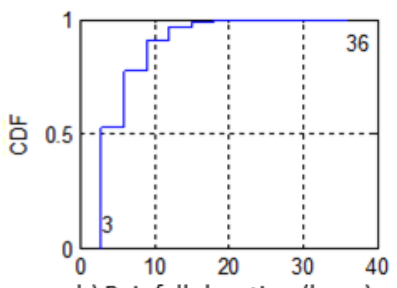

b) Rainfall duration (hour)

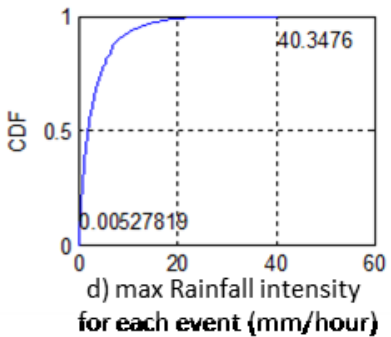

Fig. 6. The cumulative probability function of: a) amount, b) duration, c) average intensity and d) maximum intensity for each rainfall event

The diurnal rainfall analysis produced four rainfall scenarios for hydrological simulation. The scenarios named DD, DS, SS, and 2SS. DD, DS, SS is symbol for diurnal-diurnal, diurnal semidiurnal, and semidiurnalsemidiurnal respectively, where the first alphabet for upstream area and the second alphabet for the midstream area. The rainfall intensity is $15 \mathrm{~mm} /$ hour for the diurnal and $7.5 \mathrm{~mm} /$ hour for the semidiurnal with 3-hour duration for each event. Fig. 7 is the ilustration of the scenarios.

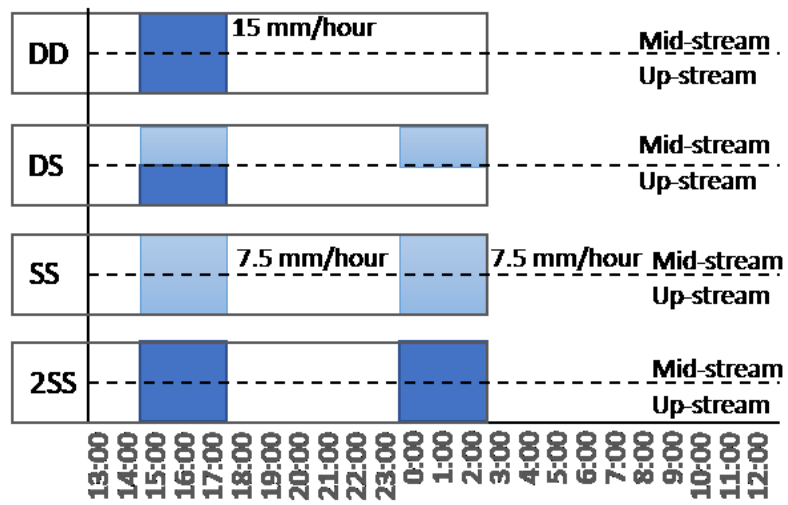

Fig. 7. Rainfall scenarios for hidrological simulation based on general patterns of diurnal rainfall

Besides of diurnal patterns, there are also other rainfall characteristics triggering the extremes discharge, which is rain propagation. Due to data limitations in Indonesia, there has few of research discuss this topic. However, several studies have mentioned their existence in CRB [6], [9], [8], [11]. Wu et al. (2013) stated the convective system that triggered major floods event in 2013 propagate to upstream by $8 \mathrm{~m} / \mathrm{s}$ of speed. Sulityowati showed that the speed of rainfall propagation can vary between $2.57-15.42 \mathrm{~m} / \mathrm{s}$ based on radar data on 9-15 February 2010[11]. Numerical model and laboratory experiment in artificial domains shows that propagated rain to downstream direction will lead to greater peak discharge. Based on this, a new parameter added to the scenario, which is the movement of rain. At this moment only considered the movement to downstream at $5 \mathrm{~m} / \mathrm{s}$ of speed. The addition of this parameter produces four additional scenarios illustrated in Fig.8.
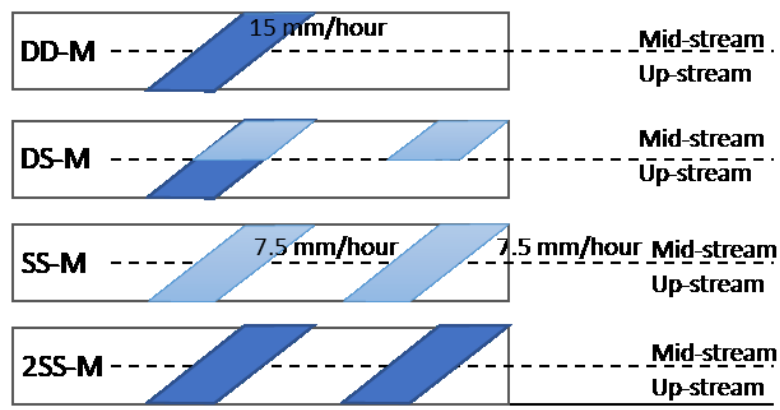

8888888888888888888888888

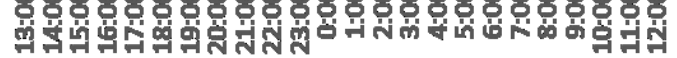

Fig. 8. As in Fig. 7, but for moving rainstorm to downstream directions

\subsection{The role of the rainfall pattern combination}

The GSSHA model was applied to produce hydrograph of discharge effected by diurnal-semidiurnal pattern of rainfall. This simulation consists of combinations of a 
simple spatiotemporal variability of daily rainfall over CRB that described in sections 3.1.

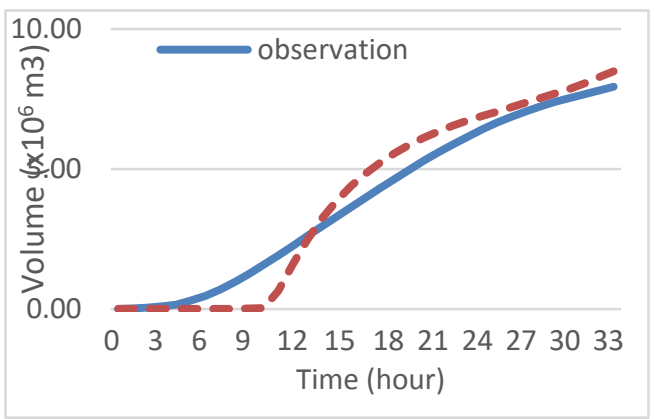

Fig. 9. Mass curve of the calibration processes

The discharge data provided by Ciliwung-Cisadane Large River Basin Agency (BBWS: Abbreviation in Indonesian) was used to calibrate the model. The calibration output showed a good agreement between observation data and simulation result for the volume of rivers discharges at outlet without any significant bias (Fig. 9). This result indicates the model parameterization was good enough to explain the role of rainfall volume on overland flow. The calibration process is produced by the roughness parameterization and the ratio of effective rainfall. That roughness value is $0.184,0.01,0.01$, and 0.001 for forests, cultivated areas, urban areas, and water bodies, respectively. Effective rainfall was used in this study is 0.7 .

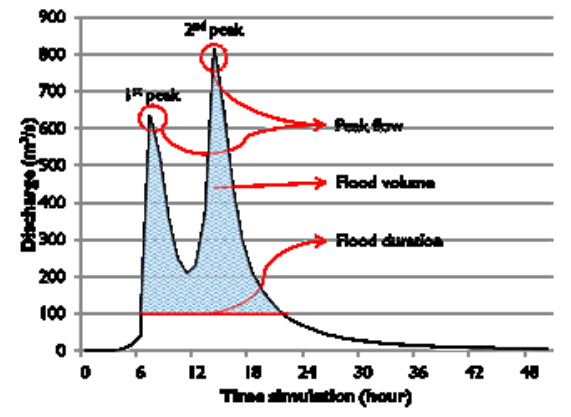

Fig. 10. The illustration of hydrological simulations results and the definition of peak flow, flood volume, and flood duration that used in this study

Fig. 10 showed an illustration of the peak flows and flood durations have been used to show the differentiation of the simulation results. There is one and two peak flow respectively for the diurnal and semidiurnal pattern of discharge. The flood durations are defined by duration where the discharge values are more than $100 \mathrm{~m}^{3} / \mathrm{s}$. This assumption based on the minimum value between two peaks on the semidiurnal pattern of the hydrograph. The other reason is the bank full discharge or flood discharge in M.T Haryono hydrological stations have not well defined.

Comparison of the DD, DS, SS and 2SS scenarios showed: 1) diurnal pattern of rainfall produced higher peak flow than semidiurnal, but 2) semidiurnal pattern of rainfall triggered semidiurnal pattern on discharge and prolong flood duration (Fig. 11). The rainfall with 15 $\mathrm{mm} /$ hour of intensity and 3 hours on the duration that occurred on the whole watershed area have produced the hydrograph with $470 \mathrm{~m}^{3} / \mathrm{s}$ of peak flow and 8 hours of flood duration. If the semidiurnal rainfall with 7.5 $\mathrm{mm} /$ hour of rainfall intensity and $2 \times 3$ hour of durations occurs, respectively in the afternoon and early morning, the hydrograph shape will be turned into semidiurnal with the values of the first and second peak flow respectively are 0.38 and 0.5 times of the peak flow of scenario DD. Besides of that, the flood duration increased from 8 hours to 11 and 13 hours on the DS and SS scenarios, respectively.

The simulation results in Fig. 11 showed the existence of the role of the diurnal-semidiurnal patterns of rainfall against to in the diurnal-semidiurnal patterns of discharge. Existence of diurnal-semidiurnal patterns of the rivers water level, generally has a logarithmic function to the discharge, has shown by result of spectral analysis conducted by Sulityowati et al. (2014) at Manggarai hydrological station (about $5 \mathrm{~km}$ to downstream area from outlet of the hydrological model in this study) [11]. The study showed the correlation between the diurnal pattern of rainfall and water level, but have no explanation about correlation for the semidiurnal pattern.

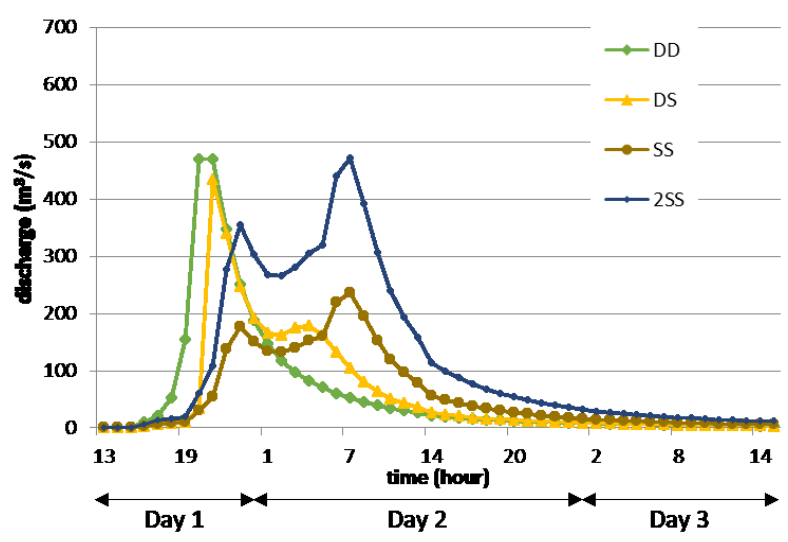

Fig. 11. Hydrographs comparison of all scenarios for stationer rainfall.

The semidiurnal pattern of discharge (Fig. 11, blue curve), the 2 nd peak flow showed a larger value than 1 st peak flow. This condition is caused by a superposition between hydrographs that produced by the afternoon and morning rain on semidiurnal rainfall. The value of the second peak will be higher when the time difference of the afternoon and morning rain is shorter. These results indicate that the semidiurnal pattern has the potential to trigger greater peak discharge for maximum rainfall intensity occur in both afternoon and morning $(15 \mathrm{~mm} /$ hour in this study, the 2SS simulation scenarios).

The 2SS scenario has twice amount of daily rainfall than the SS scenario. This scenario accordance with the 
research results from Trilaksono et al. (2012) which mentions the rain that occurred in 2007 has a semidiurnal pattern that triggered by two different convective systems. This condition has a possibility to produce two rainfall events that have maximum intensity. The result opens possibility to analyze the major flood events that occurred in 2002, 2007 and 2013 known have a long flood duration [9], [8], [12], [7].

In addition to the diurnal-semidiurnal pattern, Sulityowati et al. (2014) also explains about rain propagation that can occur to upstream or downstream direction with speeds varying between $2.57-15.42 \mathrm{~m} / \mathrm{s}$ based on radar data on 9-15 February 2010 [11]. Wu et al. (2013) stated the convective system that triggered major floods event in 2013 propagate to upstream about $8 \mathrm{~m} / \mathrm{s}$ [9]. Rain propagation was also described in Hadi et al. (2006) and Trilaksono et al. (2012) which each addressed the flood events of 2002 and 2007 [6], [8]. That research result indicates that, besides of the semidiurnal diurnal pattern, rainfall propagation also plays an important role in triggering the peak discharge that causes flooding.

The DD-M, DS-M, SS-M and 2SS-M scenarios are rainfall scenarios that combine diurnal-semidiurnal patterns of rainfall and rain propagation. The simulation results show that rain propagation to downstream area will amplify peak discharge about 1.3, 1.1, 1.2 and 1.2 times for DD, DS, SS, and 2SS patterns, respectively (Fig.12). However, this rain propagation will result in shorter flood duration.

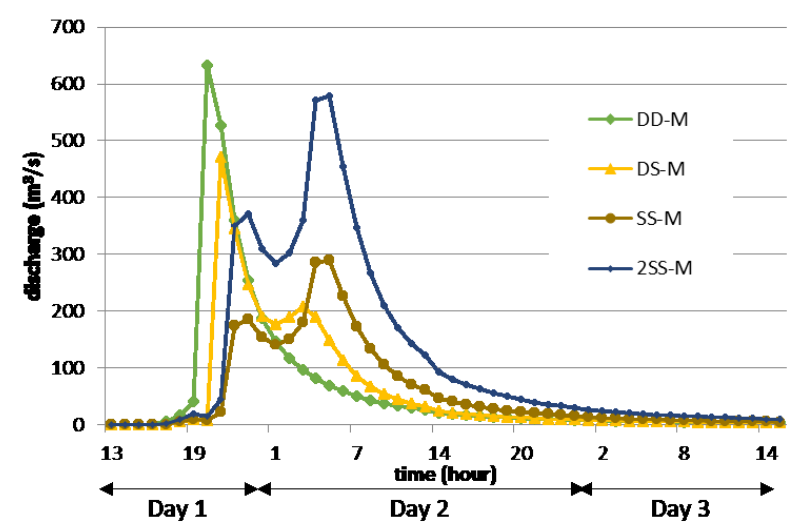

Fig. 12. As Fig.11, but for moving rainfall.

These simulation results are consistent with Ogden et al. (1995), de Lima and Singh (2002) and de Lima and Singh (2003) [1], [3], [4]. Those study also mentioned downstream movement direction will cause the opposite condition, ie lower peak discharge but longer flood duration. In the real case, the convective system causing major floods in Jakarta has varying speed and direction values, such as the 2013 flood event, the conventive system was propagated to upstream direction [9] and the 2007 flood event the convective system propagated to the downstream area at night but to the upstream area at morning [8].

\section{Conclusions}

The results of this study highlight the spatiotemporal variance of rainfall patterns and its role in peak flow and flood durations. In addition, the role of rainfall propagation also compared to the role of rainfall patterns. The result shows the rainfall pattern variated for each location and month. The semidiurnal pattern becomes dominant in the whole area of CRB in January and February which is the months with most frequent major floods in CRB. Based on the hydrological model simulation, for the equal amount of daily rainfall (a single event for semidiurnal pattern): (1) the diurnal pattern will produce higher peak-flow than the semidiurnal pattern of rainfall and (2) vice versa for flood duration. The double amount of rainfall for the semidiurnal pattern will produce higher peak-flow and flood durations. This conditions will be enlarger by the moving rainstorm to downstream directions.

The results of this research indicate there are two factors that trigger major floods are: (1) semidiurnal pattern of rainfall that occurs in the whole of the watershed, (2) the rainfall propagation to downstream area. Both of these factors need to be studied further in real cases.

This research was funded by Riset ITB 2017 and was the part of "Peranan Hujan yang Bergerak terhadap Debit Ekstrem di Sungai Ciliwung" research.

\section{References}

[1] F. L. Ogden, J. R. Richardson, and P. Y. Julien, "Similarity in Catchment Response: 2. Moving Rainstorms," Water Resources Research, vol. 31, no. 6, pp. 1543-1547, 1995.

[2] V. P. Singh, "Effect of spatial and temporal variability in rainfall and watershed characteristics on stream flow hydrograph," Hydrological Processes, vol. 11, no. 12, pp. 1649-1669, 1997.

[3] J. L. M. P. De Lima and V. P. Singh, "The influence of the pattern of moving rainstorms on overland flow," Advances in Water Resources, vol. 25, no. 7, pp. 817-828, 2002.

[4] J. L. M. P. de Lima and V. P. Singh, "Laboratory experiments on the influence of storm movement on overland flow," Physics and Chemistry of the Earth, vol. 28, no. 6-7, pp. 277-282, 2003.

[5] A. Formánek, R. Silasari, M. S. B. Kusuma, and H. Kardhana, "Two-Dimensional Model of Ciliwung River Flood in DKI Jakarta for Development of the Regional Flood Index Map," Journal of Engineering and Technological Sciences, vol. 45, no. 3, pp. 307-325, 2013.

[6] T. W. Hadi, N. J. Trilaksono, and I. D. G. Junnaedhi, "A Numerical Study of The Jakarta Flood Event of January / February 2002 : Simulation of Convective Rainfall Using Regional Weather Model," Bandung, 2006. P. Wu et al., "The Impact of Trans-equatorial Monsoon Flow on the Formation of Repeated Torrential Rains over Java Island," Sola, vol. 3, 
no. February, pp. 93-96, 2007.

[8] N. J. Trilaksono, S. Otsuka, and S. Yoden, “A Time-Lagged Ensemble Simulation on the Modulation of Precipitation over West Java in January-February 2007," Monthly Weather Review, vol. 140, no. 2, pp. 601-616, 2012.

[9] P. Wu et al., "The effects of an active phase of the Madden-Julian oscillation on the extreme precipitation event over western Java Island in January 2013," Sola, vol. 9, no. January, pp. 7983, 2013.

[10] Bappenas, "Laporan Perkiraan Kerusakan dan Kerugian Pasca Bencana Banjir Awal Februari 2007 di Wilayah JABODETABEK Jakarta, Bogor, Depok, Tangerang, dan Bekasi)," Jakarta, 2007.

[11] R. Sulistyowati, R. I. Hapsari, F. Syamsudin, S. Mori, S. T. Oishi, and M. D. Yamanaka, "Rainfall-Driven Diurnal Variations of Water Level in the Ciliwung River, West Jawa, Indonesia," Sola, vol. 10, no. 0, pp. 141-144, 2014.

[12] M. Wheeler, "The Madden Julian Oscillation and the Java floods of January/February 2002," BMRC Modeling Workshop, no. February, 2002. 